\title{
Fabrication of $\mathrm{CdTe} / \mathrm{Si}$ heterojunction solar cell
}

\author{
Swades Ranjan Bera ${ }^{1} \cdot$ Satyajit Saha $^{1}$
}

Received: 3 November 2015/ Accepted: 18 December 2015/Published online: 7 January 2016

(C) The Author(s) 2016. This article is published with open access at Springerlink.com

\begin{abstract}
A simple cost effective method is preferred to grow nanoparticles of CdTe. Nanoparticles of CdTe are grown by simple chemical reduction route using EDA as capping agent and Sodium Borohydride as reducing agent. The grown nanoparticles are characterized using transmission electron microscopy (TEM), X-ray diffraction, optical absorption, and photoluminescence study. From optical absorption study, the band-gap was found to be $2.46 \mathrm{eV}$. From TEM study, the average particle size was found to be within $8-12 \mathrm{~nm}$ which confirms the formation of CdTe nanoparticles. Pl spectra indicate the luminescence from surface states at $2.01 \mathrm{eV}$, which is less compared to the increased band-gap of $2.46 \mathrm{eV}$. The grown nanoparticles are used to fabricate a heterojunction of $\mathrm{CdTe}$ on P-Si by a spin coating technique for solar cell fabrication in a cost effective way. I-V characteristics of the grown heterojunction in dark as well as under light are measured. Efficiency and fill-factor of the device are estimated.
\end{abstract}

Keywords Nanostructures - Semiconductors - Chemical synthesis · Transmission electron microscopy (TEM) . Electrical properties

Satyajit Saha

sahaphys.vu@gmail.com

Swades Ranjan Bera

swadesbera@gmail.com

1 Department of Physics and Technophysics, Vidyasagar University, Midnapore 721102, West Bengal, India

\section{Introduction}

Semiconductor nanoparticles, which exhibit properties different from bulk materials, are a new class of materials that hold considerable promise for numerous applications in the field of electronics and photonics. Nanoscale modification of the molecular design and morphology of such particles provides a powerful approach toward control of their electrical and optical properties (Whitesides et al. 2002; Duan et al. 2003; McAlpine et al. 2003; Wang et al. 2007; Mehta et al. 2005; Ernst et al. 2003; Yang et al. 2000; Ehsan et al. 2012; Pinheiro et al. 2006). Among the colloidal nanocrystals, CdTe (generally Gr-II to Gr-VI) is studied because of the efficiency of its synthesis, the high quality of the resulting sample, and the fact that the optical gap lies in the visible range. Also it is an important semiconducting material with unique electrical properties, which makes it a promising material in the field of optoelectronic devices such as light emitting diodes, solar cells, photo detectors, biosensors, etc. (Singh et al. 2003, 2004; Dai et al. 1995; Duan et al. 2001; Holmes et al. 2000; Gates et al. 2001; Martin et al. 1994; Peng et al. 2000; Nicewarner-Pena et al. 2001; Yu et al. 2000). In the present work, a simple chemical reduction method is followed to grow CdTe nanoparticles. In the last few decades, continuously increasing demand of alternative renewable energy sources has stimulated new scientific researches in the field of photovoltaic devices (Alnajjar et al. 2009). The use of silicon ( $\mathrm{Si}$ ) as substrate material has many advantages, it is an obvious goal due to its mechanical strength, low price, and compatibility with standard Si-based device processing (Suela et al. 2010). On the other hand, material-related issues like including thermal expansion mismatch could also have an impact on dislocation densities or other important defects in CdTe/Si composite (Jacobs et al. 
2008). Solar energy is one particularly relevant application due to the rising monetary and environmental cost of fossil fuels (Garnett et al. 2008). One of the primary barriers to widespread photovoltaic (PV) used, is PV cell production cost, nearly half of which is imbedded in the initial Sillicon wafer (Garnett et al. 2008). CdTe has been shown to be the most promising polycrystalline thin film material for producing PV solar cells because of its high absorption coefficient $\left(\alpha>10^{4} \mathrm{~cm}^{-1}\right)$ and optimum band gap $(1.5 \mathrm{eV})$. Several research works are going on to increase the efficiency of inorganic PV devices. An attempt is made here to fabricate heterojunction solar cells of CdTe nanoparticles, coated on P-Si by a simple spin coating technique (Jacobs et al. 2008; Suela et al. 2010; Garnett et al. 2008).

\section{Experiment}

Anhydrous $\mathrm{CdCl}_{2}$ (molecular weight $201.32 \mathrm{~g} / \mathrm{mol}$ ) (603.96 mg), Tellurium (molecular weight $127.6 \mathrm{~g} / \mathrm{mole}$ ) (382.8 $\mathrm{mg}$ ) powder and sodium borohydride (molecular weight $37.83 \mathrm{~g} / \mathrm{mole})(113.49 \mathrm{mg}$ ) have been taken to prepare CdTe. Ethylenediamine has been used as a capping agent. Sodium borohydride has been taken to initiate the reaction at room temperature. The prepared solution is taken in a beaker. The solution is stirred for $3 \mathrm{~h}$ at a particular speed $(6000 \mathrm{rpm})$ using a magnetic stirrer. The reactions are as follows.

$$
\begin{aligned}
& \mathrm{CdCl}_{2}=\mathrm{Cd}^{++}+2 \mathrm{Cl}^{-} \\
& 2 \mathrm{NaBH}_{4}+2 \mathrm{Cl}^{-}=2 \mathrm{NaCl}+\mathrm{B}_{2} \mathrm{H}_{6}+2 \mathrm{H}+2 \mathrm{e} \\
& 2 \mathrm{H}+\mathrm{Te}=\mathrm{H}_{2} \mathrm{Te} \\
& \mathrm{H}_{2} \mathrm{Te}+\mathrm{Cd}^{++}+2 \mathrm{e}=\mathrm{CdTe}+\mathrm{H}_{2}
\end{aligned}
$$

The transmission electron micrograph of the as-prepared samples has been taken using a JEOL-JEM-200 transmission electron microscope operating at $200 \mathrm{kV}$. The particle size is found to be within $8-12 \mathrm{~nm}$. The size can be varied by varying the growth temperature (Saha et al. 2013). Optical absorption measurements of the dispersed samples have been studied in the range of 300-700 nm using a Shimadzu Pharmaspec 1700 UV-VIS Spectrophotometer. Photoluminescence study is done in the range of 200-900 nm using Perkin Elmer LS-55 PL spectrometer. The photovoltaic devices in this study comprises of a heterojunction layer of $\mathrm{n}-\mathrm{CdTe} / \mathrm{p}-\mathrm{Si}(100)$. $\mathrm{p}$-Si wafer is cleaned using standard RCA process followed by etching in $1 \%$ dilute hydrofluoric acid (HF) solution to
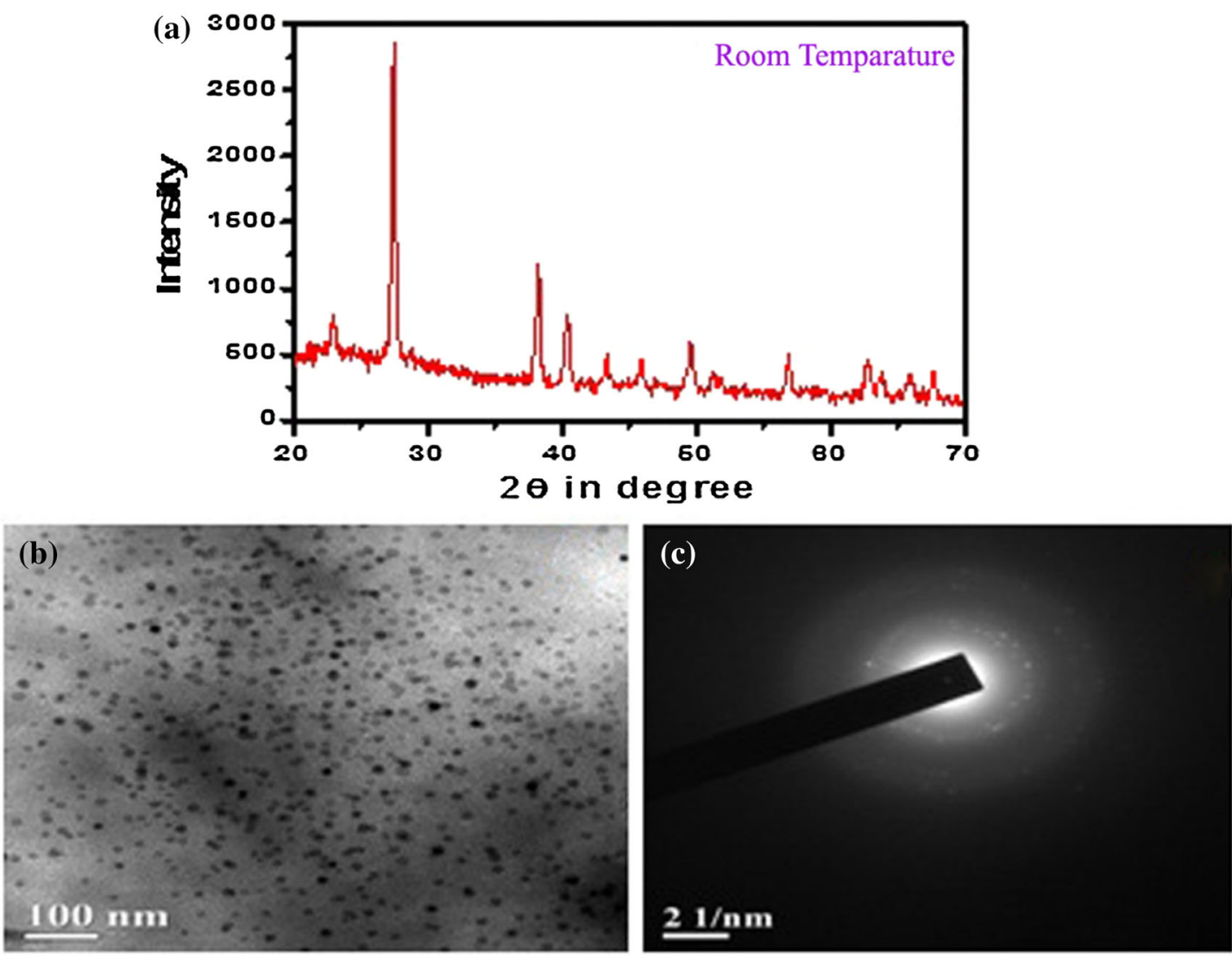

Fig. 1 a XRD pattern of CdTe- nanoparticles, b HRTEM image of CdTe-nanoparticles, c SAED pattern of CdTe nanoparticles 

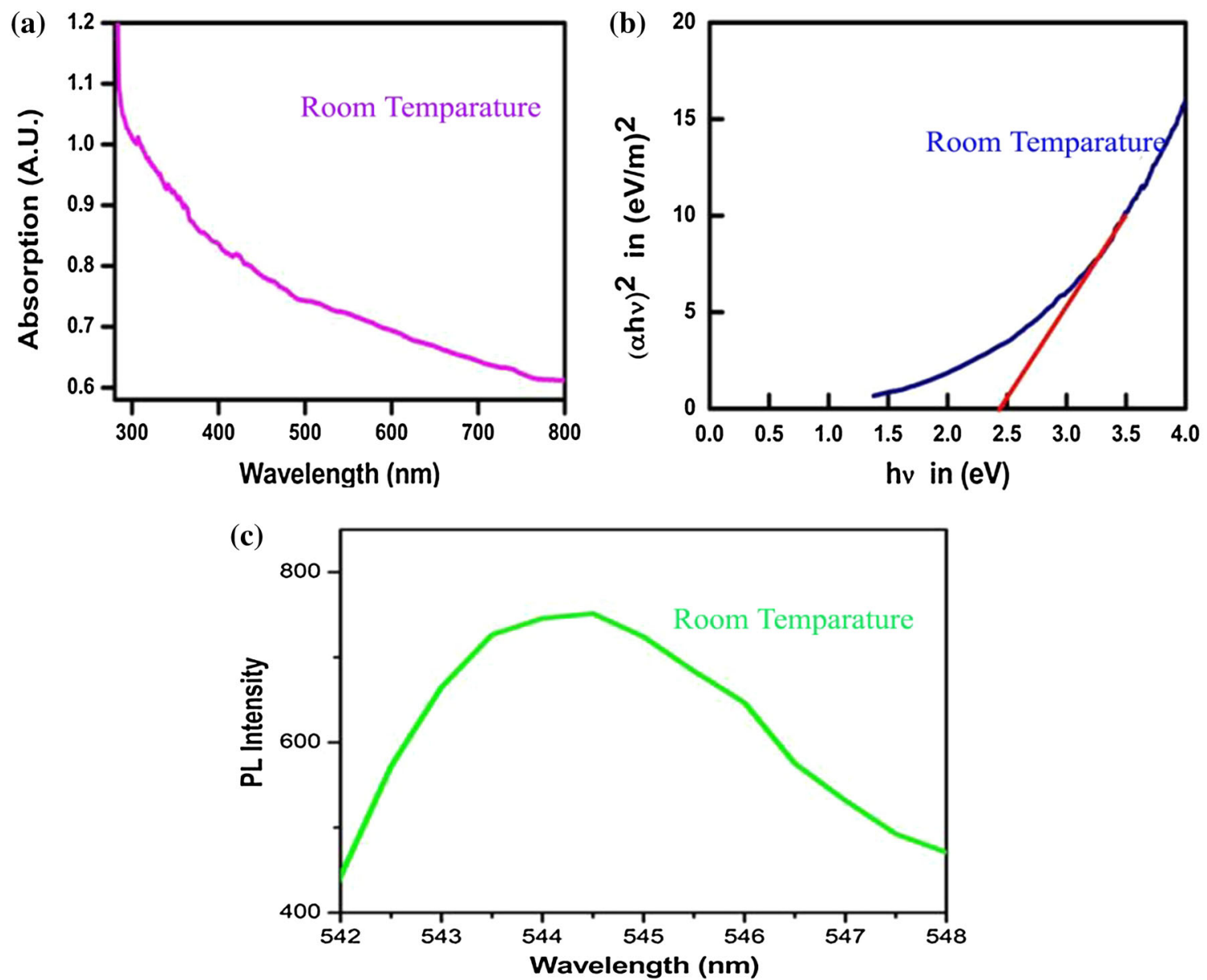

Fig. 2 a Plot of optical absorption with wavelength for CdTe nanoparticles, b Plot of $(\alpha h v)^{2}$ vs. energy $(h v)$ to determine band gap, $\mathbf{c}$ Plot of photoluminescence intensity vs wavelength for CdTe nanoparticles

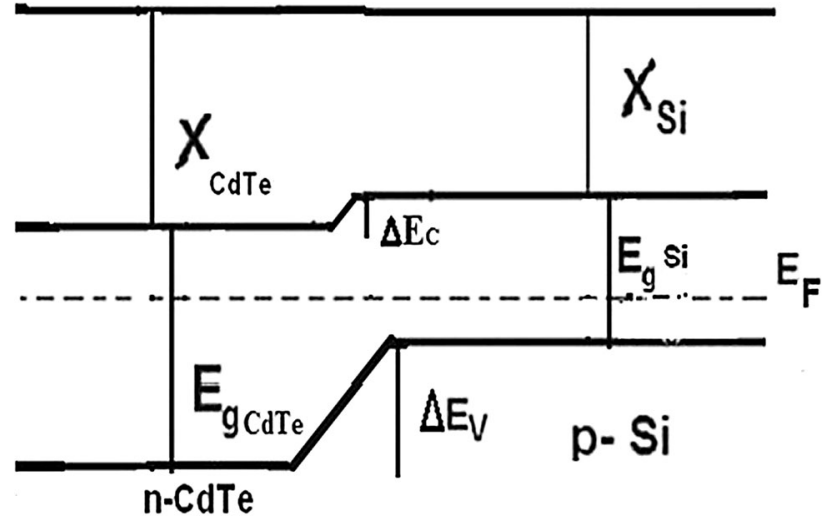

Fig. 3 Energy band diagram for n-CdTe/P-Si(100) heterojunction

remove the native oxide layer. CdTe nanoparticles dispersed in ethanol are slowly injected on to the $\mathrm{Si}$ wafer rotating with a constant speed (1500 rpm). A uniform layer of CdTe nanofilm is coated on to $\mathrm{P}-\mathrm{Si}$ wafer. The thickness of the CdTe layer is measured using

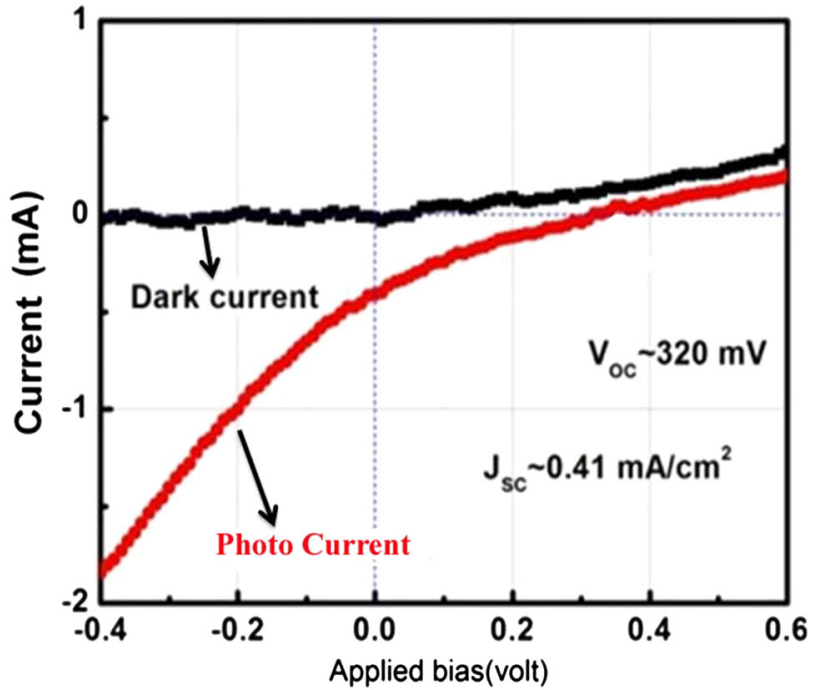

Fig. 4 I-V characteristics of n-CdTe nanoparticles/p-Si(100) heterojunction 
Surfometer. The sample is baked for few minutes at $40{ }^{\circ} \mathrm{C}$ temperature and the device is formed. $\mathrm{Al}$ is deposited by vacuum evaporation on CdTe nanofilm with a contact area of $4 \times 10^{-3} \mathrm{~cm}^{2}$. Hence the device area is $4 \times 10^{-3} \mathrm{~cm}^{2}$. Current density-voltage $(\mathrm{J}-\mathrm{V})$ characteristics of the devices in dark and under air mass (AM) 1.5 illumination (XES-151S) with a power density of $100 \mathrm{~mW} / \mathrm{cm}^{2}$ were measured using Agilent B1500A semiconductor device analyzer.

\section{Result and discussion}

\section{Structural determination using XRD}

The powder X-ray diffraction (XRD) pattern of CdTe sample was recorded by a X-ray diffractometer (miniflex II, desktop-X-ray diffractometer) using $\mathrm{Cu}-\mathrm{k} \alpha$ radiation in the range of Bragg angle (20) from $20^{\circ}$ to $70^{\circ}$. Figure 1a shows the XRD patterns of the sample. The peaks are identified comparing with ICDD data (Tiwari et al. 2013; Saha et al. 2013). The nanoparticles formed are of CdTe which is confirmed. X-ray diffraction pattern of blackish powder of CdTe nanoparticles, obtained by chemical reduction method, is shown in Fig. 1a. The XRD pattern of nanoparticles matches with JCPDS file No. 75-2083, which again have face centered cubic structure of crystallites with same lattice parameter as estimated for nanoparticles obtained.

Average particle size of crystallites is calculated by Debye Scherer equation.

$P=k \lambda /(\beta \cos \theta)$

where $k$ is the shape factor, the dimensionless shape factor has typical value $0.9, \lambda$ is the $\mathrm{X}$-ray wavelength $0.154 \mathrm{~nm}$, $\beta$ is the line broadening at half the maximum intensity (FWHM) in radians, and $\theta$ is the Bragg angle; $P$ is the mean size of the ordered (crystalline) domains. Average sizes of crystallite calculated from Debye Scherer equation, is $27.57 \mathrm{~nm}$ for CdTe.

\section{Morphological study using TEM}

Morphologies of the products synthesized at $300 \mathrm{~K}$ are shown in Fig. 1b. HRTEM image shows particles like nano structure of CdTe grown at $300 \mathrm{~K}$. The average particle size estimated from the HRTEM is found to be within 8-12 nm (Saha et al. 2013; Perez-Conde et al. 2001; Milleron et al. 2005; Neretina et al. 2008). SAED pattern is shown in Fig. 1c. Diffraction pattern indicates single crystalline phase is present.

\section{Optical properties of CdTe-nanostructure}

The CdTe nanoparticles were dispersed in spectroscopic grade Tolluene for optical absorption measurements. Optical properties of CdTe nanoparticles were determined through UV-VIS absorbance spectroscopy. Figure $2 \mathrm{a}$ shows the optical absorbance spectra of CdTe samples. Optical absorption coefficient has been calculated in the Wavelength

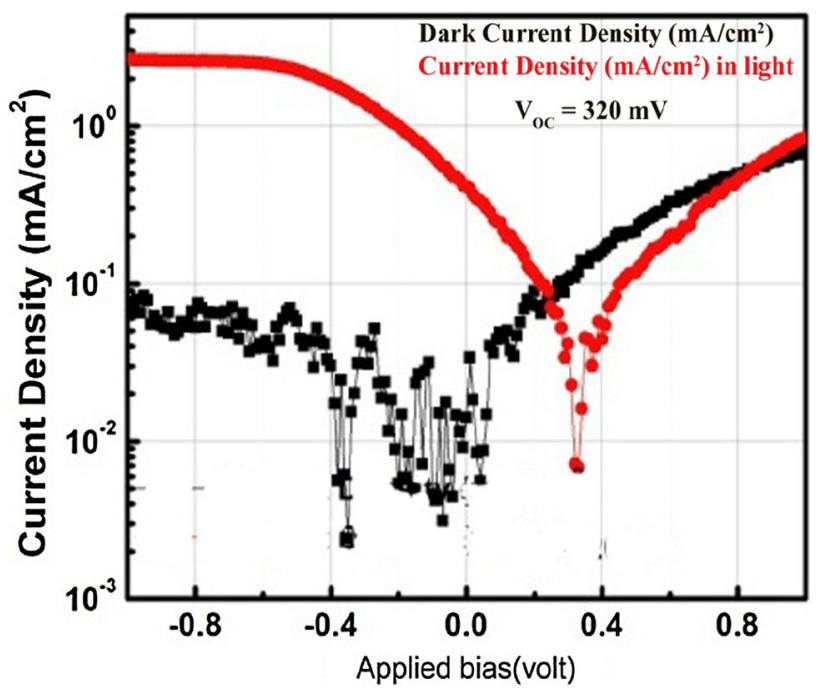

Fig. $5 \mathrm{~J}-\mathrm{V}$ characteristics of $\mathrm{n}-\mathrm{CdTe}$ nanoparticles/p-Si(100) heterojunction

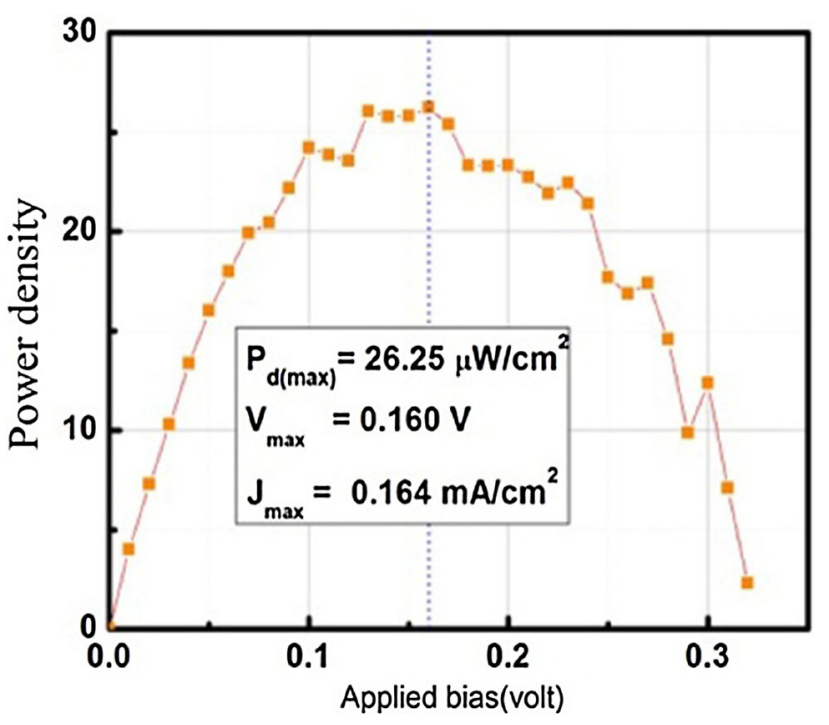

Fig. 6 Variation of power density of n-CdTe nanoparticles/p-Si(100) heterojunction 
Table 1 Structural, optical parameters of n-CdTe nanoparticles and electrical parameters of n-CdTe/p-Si heterojunction

\begin{tabular}{|c|c|c|c|c|c|c|c|c|c|}
\hline \multicolumn{4}{|c|}{ Structural and optical results of the CdTe nanoparticles } & \multicolumn{6}{|c|}{ Electrical results of the n-CdTe/p-Si heterojunction } \\
\hline $\begin{array}{l}\text { Growth } \\
\text { temp. }\end{array}$ & $\begin{array}{l}\text { Shape of } \\
\text { particles }\end{array}$ & $\begin{array}{l}\text { Average diameter of the } \\
\text { particle }(\mathrm{nm})\end{array}$ & $\begin{array}{l}\text { Band } \\
\text { Gap }(e V)\end{array}$ & $V_{\max }(\mathrm{V})$ & $\begin{array}{l}J_{\max } \\
\left(\mathrm{mA} / \mathrm{cm}^{2}\right)\end{array}$ & $V_{\mathrm{OC}}(\mathrm{V})$ & $\begin{array}{l}J_{\mathrm{SC}} \\
\left(\mathrm{mA} / \mathrm{cm}^{2}\right)\end{array}$ & $\begin{array}{l}\text { Fill factor } \\
(\%)\end{array}$ & $\begin{array}{l}\text { Efficiency } \\
(\%)\end{array}$ \\
\hline $300 \mathrm{~K}$ & Spherical & 10 & 2.46 & 0.16 & 0.164 & 0.32 & 0.41 & 20 & 0.026 \\
\hline
\end{tabular}

region $300-700 \mathrm{~nm}$. The band gap of the as-prepared nanoparticles is determined from the relation $(\alpha h \gamma)^{2}=c\left(h \gamma-E_{g}\right)$, where $c$ is a constant. $E_{g}$ is the direct band gap of the material and $\alpha$ is the absorption coefficient. Figure $2 \mathrm{~b}$ shows the plot of $(\alpha h v)^{2}$ vs. energy $(h v)$ and the band gap of the sample is found to be $2.46 \mathrm{eV}$. The band gap is greater than the bulk CdTe (Perez-Conde et al. 2001; Manna et al. 2003; Wuister et al. 2004) band gap. Thus there is a blue shift relative to the peak absorption of bulk CdTe.

\section{Photoluminescence of CdTe-nanostructure}

The study of photo luminescence spectra is an effective method that evaluates defect states The PL spectra of the CdTe nanoparticles were measured with excitation wavelength $360 \mathrm{~nm}$ (Fig. 2c). The peak arises at $545 \mathrm{~nm}$ due to luminescence from surface states (Saha et al. 2013; Wuister et al. 2003; Mohammed et al. 2013) just below the conduction band.

\section{Behavior of n-CdTe/p-Si Heterojunction}

The possible heterostructure of n-CdTe/p-Si are shown in Fig. 3. The conduction band edge and the valence band edge are estimated using the releations $\Delta E_{C}=\chi_{1 \mathrm{CdTe}}-$ $\chi_{2 \mathrm{Si}}=(4.40-4.05)=0.35 \mathrm{eV} \quad$ while $\Delta E_{V}=$ $\left(E_{g(\mathrm{CdTe})}-E_{g(\mathrm{Si})}\right)-\Delta E_{C}=1.36-0.35=1.01 \mathrm{eV}$. The band gap of CdTe nanoparticles is $2.46 \mathrm{eV}$. When light falls on $\mathrm{CdTe}$, the minority carriers holes are generated on n-CdTe due to transition of electrons from valence band to conduction band. The hole feels the electric field at the junction and constitutes the photocurrent.

The electrical characteristics of the photovoltaic cells were investigated in the dark and light under different bias conditions. The dark $\mathrm{I}-\mathrm{V}$ and $\mathrm{I}-\mathrm{V}$ curve under light is measured in forward and reverse directions as shown in Fig. 4. In the forward biasing condition, there is a small shift of the I-V curve under light with respect to the dark. The important solar cell parameters like short circuit current density $I_{\mathrm{sc}}$, open-circuit voltage Voc, and maximum out putted power $(\mathrm{Pm})$ were determined. During dark I-V measurements, a light-proof cover shields the cell under test. The devices exhibit conventional rectifying diode characteristics as expected from any heterojunction devices. J-V characteristics under AM $1.5\left(100 \mathrm{~mW} / \mathrm{cm}^{2}\right)$ solar irradiation conditions of the same devices are displayed in Fig. 5. Figure 6 shows a variation of power density of nCdTe nanoparticles/p-Si(100) heterojunction structure. A maximum, $0.026 \%$ power conversion efficiency is achieved for the cell having $50 \mathrm{~nm}$ layer of the device was measured using the relations:

$\mathrm{FF}=\left(I_{m} \times V_{\mathrm{m}}\right) /\left(I_{\mathrm{SC}} \times V_{\mathrm{OC}}\right)$ and $\eta=\left(V_{\mathrm{OC}} \times I_{\mathrm{SC}} \times \mathrm{FF}\right) / P_{\text {in }}$

where $V_{\mathrm{oc}}$ is the open-circuit voltage, $I_{\mathrm{sc}}$ is the short circuit current, FF is the fill factor, $\eta$ is the power conversion efficiency and $P_{\text {in }}$ is the incident light power density, $I_{\mathrm{m}}$ and $V_{\mathrm{m}}$ are the current and voltage at the maximum power point. The lower efficiency is probably due to the loss of carriers due to recombination within CdTe layer (Mohammad et al. 2012; Romeo et al. 2004; Bonnet et al. 2002; Romeo et al. 1998). This is possibly due to surface states which are present in the nanostructured CdTe film. The different parameters extracted from the device are shown in the Table 1.

\section{Conclusions}

The nanoparticles are grown at room temperature in a cost effective way. The chemical reduction route is a simple cost effective way to grow nanoparticles of CdTe compared to other conventional method of growing nanocrystals of CdTe. The grown nanoparticles are characterized structurally and optically. The nanofilm of CdTe is grown on P-Si by using nanoparticles applying a simple technique, i.e. a spin coater. The fabricated heterojunction shows photovoltaic effect. The small photovoltaic properties are largely due to the lattice mismatch which is responsible for structural defects that reduce device performance.

Acknowledgments The authors are grateful to UGC (SAP Programme) and DST (FIST Programme) for their constant support for providing various instrumental facilities to Physics and Technophysics department of Vidyasagar University.

Open Access This article is distributed under the terms of the Creative Commons Attribution 4.0 International License (http:// creativecommons.org/licenses/by/4.0/), which permits unrestricted use, distribution, and reproduction in any medium, provided you give appropriate credit to the original author(s) and the source, provide a link to the Creative Commons license, and indicate if changes were made. 


\section{References}

Alnajjar AA, Alias MFA, Almatuk RA, Al-Douri AA (2009) The characteristic of anisotype $\mathrm{CdS} / \mathrm{CdTe}$ heterojunction. Renew Energy 34:2160-2163

Bonnet D, Oelting S, Harr M, Will S (2002) Start-up and operation of an integrated $10 \mathrm{MWp}$ thin film PV module factory. In: Proceedings of the 29th IEEE Photovoltaic Specialists Conference, Anaheim, pp 563-566

Dai H, Wong EW, Lu YZ, Fan S, Lieber CM (1995) Synthesis and characterization of carbide nanorods. Nature 375(6534):769-772

Duan XF, Huang Y, Cui Y, Wang JF, Lieber CM (2001) Indium phosphide nanowires as building blocks for nanoscale electronic and optoelectronic devices. Nature 409(6816):66-69

Duan X, Niu C, Sahi V, Chen J, Parce JW, Empedocles S, Goldman JL (2003) High-performance thin film transistors using semiconductor nanowires and nanoribbons. Nature 425:274-278. doi:10.1038/nature01996

Ehsan MH, Dizaji HR, Mirha MH (2012) The vapor controller effect on physical properties of CdTe thin films. Dig J Nanomater Biostruct 7:629-636

Ernst K, Belaidi A, Konenkamp R (2003) Solar cell with extremely thin absorber on highly structured substrate. Semicond Sci Technol V-18:475

Garnett EC, Yang P (2008) Silicon nanowire radial $\mathrm{p}-\mathrm{n}$ junction solar cells. J Am Chem Soc 130:9224

Gates B, Wu Y, Yin Y, Yang P, Xia Y (2001) Single-crystalline nanowires of $\mathrm{Ag}_{2} \mathrm{Se}$ can be synthesized by templating against nanowires of trigonal Se. J Am Chem Soc 123(46):11500-11501. doi:10.1021/ja0166895

Holmes JD, Johnston KP, Doty RC, Kor- gel BA (2000) Control of thickness and orientation of solution-grown silicon nanowires. Science 287(5457):1471-1473

Jacobs RN, Almeida LA, Markunas J, Pellegrino J, Groenert M, Jaime-Vasquez M, Mahadik N, Andrews C, Qadri SB, Lee T, Kim M (2008) Comparative study of thermal mismatch effects in $\mathrm{CdTe} / \mathrm{Si}, \mathrm{CdTe} / \mathrm{Ge}$, and $\mathrm{CdTe} / \mathrm{GaAs}$ composite structures: CS MANTECH, Conference, Chicago, Illinois, USA

Manna L, Milliron DJ, Meisel A, Scher EC, Alivisatos AP (2003) Controlled growth of tetrapod-branched inorganic nanocrystals. Nat Mater 2:382-385

Martin CR (1994) Nanomaterials: a membrane-based synthetic approach. Science 266(5193):1961-1966. doi:10.1126/science. 266.5193.1961

McAlpine MC, Friedman RS, Jin S, Lin K, Wang WU, Lieber CM (2003) High performance nanowire electronics and photonics on glass and plastic substrates. Nano Lett 3:1531-1535. doi:10. $1021 / \mathrm{n} 10346427$

Mehta BR, Kruis FE (2003) A graded diameter and oriented nanorodthin film structure for solar cell application: a device proposal. Solar Energy Mater Solar Cells (2005) 85(1):107-113

Milleron DJ, Gur I, Alivisatos AP (2005) Hybrid organic-nanocrystal solar cells. MRS Bull 30(1):41-44. doi:10.1557/mrs2005.8

Mohammad WF (2012) The effects of fabrication parameters and electroforming phenomenon on $\mathrm{CdTe} / \mathrm{Si}$ (p) heterojunction photovoltaic solar cell. Circuits Syst 3:42-47. doi:10.4236/cs. 2012.31007

Neretina S, Hughes RA, DeVenyi GA, Sochinskii NV, Preston JS, Mascher P (2008) The role of substrate surface alteration in the fabrication of vertically aligned $\mathrm{CdTe}$ nanowires.
Nanotechnology 19(18) Article ID. 185601. doi:10.1088/09574484/19/18/185601

Nicewarner-Pena SR et al (2001) Submicrometer metallic barcodes. Science 294(5540):137-141. doi:10.1126/science.294.5540.137

Peng XG, Manna L, Yang WD, Wickham J, Scher E, Kadavanich A, Alivisatos AP (2000) Shape control of CdSe nanocrystal. Nature 404(6773):59-61

Perez-Conde J, Bhattacharjee AK (2001) Photoluminescence Stokes shift and exciton fine structure in CdTe nanocrystals. Phys Rev B 64:113303

Pinheiro WA, Falcão VD, de Oliveira Cruz LR, Ferreira CL (2006) Comparative study of CdTe sources used for deposition of CdTe thin films by close spaced sublimation technique. Mater Res 91:47. doi:10.1590/S1516-14392006000100010

Razooqial MA, Abdulameer AF, Hameed AN, Abdullaha RA, Sabbar EI (2013) The electrical characterization of p-CdTe/n-Si (111) heterojunction diode. Adv Mater Res 702:236-241

Romeo A, Tiwari AN, Zogg H, Wagner M, Günter JR (1998) Influence of transparent conducting oxides on the properties of $\mathrm{CdTe} / \mathrm{CdS}$ solar cells. In: Proceedings of the 2nd World Photovoltaic Solar Energy Conference, Vienna, pp 1105-1108

Romeo A, Terheggen M, Abou-Ras D, Bätzner DL, Haug FJ, Kälin M, Rudmann D, Tiwari AN (2004) Development of thin-film $\mathrm{Cu}(\mathrm{In}, \mathrm{Ga}) \mathrm{Se} 2$ and $\mathrm{CdTe}$ solar cells. Prog Photovolt Res Appl 12:93-111

Saha S, Bera SR (2013) Growth and characterization of CdTe nanostructures grown by chemical reduction route. Int $\mathrm{J}$ Metall Mat Sci Eng (IJMMSE) 3(1):37-40

Sander FW, Donega C, de M, Meijerink A (2004) Luminescence temperature antiquenching of water soluble CdTe quantum dots: role of the solvent. J Am Chem Soc 126(33):10397-10402

Singh VP, McClure JC (2003) Design issues in the fabrication of CdS-CdTe solar cells on molybdenum foil substrates. Sol Energy Mater Sol Cells 76:369-385

Singh VP, Singh RS, Thompson JW, Jayaraman V, Sanagapalli S, Rangari VK (2004) Characteristics of nanocrystalline CdS films fabricated by sonochemical, microwave and solution growth methods for solar cell applications. Sol Energy Mater Sol Cells 81:293-303

Suela J, Ribeiro IRB, Ferreira SO, Malachias A, Fontes GN, Montoro LA, Ramirez AJ (2010) Evolution of crystalline domain size and epitaxial orientation of $\mathrm{CdTe} / \mathrm{Si}(111)$ quantum dots. J Appl Phys 107:064305-1

Tiwari AK, Verma VK, Jain TA, Bajpai PK (2013) Conclusive growth of CdTe nanorods by solvothermal decomposition using single source precursors. Soft Nanosci Lett 3:52-57

Wang W, Chen C, Lin K-H, Fang Y, Lieber CM (2007) Nanosensors. US 2007/0264623 A1

Whitesides GM, Bartosz G (2002) Self-assembly at all scales. Science 295:2481-2421

Wuister SF, Van Driel F, Meijerink A (2003) Luminescence and growth of CdTe quantum dots and clusters. Phys Chem Chem Phys 5:1253-1258

Yang J, Yang XL, Yu SH, Liu XM, Qian YT (2000) CdTe nanocrystallites with different morphologies and phases by solvothermal process. Mater Res Bull 35:1509-1515

$\mathrm{Yu}$ JS et al (2000) Template synthesis of polymer-insulated colloidal gold nanowires with reactive ends. Chem Commun 24:2445-2446. doi:10.1039/b007999p 